\title{
Notes and News
}

\section{THE TALAYOTS OF MAJORCA}

The pre-historic inhabitants of the Balearic Islands built small stone forts or towers, called ' talayots.' These are either rectangular or round, and occur either singly or in groups. The stones of which they are constructed are sometimes very large-two of these in a tower at La Canova, near Arta, are twelve feet long and three feet wide ; and the walls are fourteen feet thick. The surface around it is thickly strewn with potsherds, including fragments of red glazed ware,-like the Samian pottery found on Romano-British sites,-and fragments of amphorae, proving that it was occupied during the early part of the Christian era. On the other hand, bronze objects of the Bronze Age have also been found in talayot settlements, and some of these objects can hardly be later than 1000 B.c. This implies a long period, during which one might expect to find evidence of development in the methods of construction of the talayots. It seems possible that the earliest forms of settlement may have been normal hill-forts with stone walls, such as occur on the tops of several of the hills of the island; and that the talayot settlements with their towers may be a later type of fortified village adapted to the lower ground. Several of the smaller hills around Arta are crowned by small round forts, consisting simply of a wall of big stones roughly squared, set round the top of the hill. This seems to represent a primitive type such as one might suppose to be earlier than the more elaborate villages. Some of the forts contain citadels in the centre, the best example being that of Encinar des Payeses. The main entrance is four feet wide and covered by a single lintel-stone, six feet long and two and a half feet thick ; it rests on two uprights, one of which is seven and a half feet high, and has been dressed to receive the lintel. There is a similar, but smaller ' trilithon' entrance in the opposite side, now blocked up. In the centre is a citadel with a sloping ramp. There are remains of walls everywhere inside. There is much pottery lying about, some of it plainly of Roman date-Roman coins have been found here-but some of it probably earlier. 


\section{NOTES AND NEWS}

The main entrance is familiar to all archaeologists, it is illustrated in Cartailhac's Monuments primitifs des Iles baléares, and in many textbooks. It is regrettable that the whole fort should be threatened with destruction, for building purposes; and it is to be hoped that the endeavours to preserve it will succeed. To many, this fort and its gateway are typical of Balearic archaeology. It may be suggested that the free-standing towers represent the central citadel of forts such as Encinar, adapted to the needs of a settlement on lower ground.

\section{IRISH MEGALITHS}

A recent visit to New Grange, the most celebrated of Irish megalithic tombs, convinced one that it must have been constructed in the Bronze Age. There is presumptive evidence in support of this view, but one piece of direct evidence has hitherto been overlooked. The central burial-chamber is approached by a long passage, narrowest near the middle. This passage is flanked with upright stones, several of which are ornamented with sculptured designs. (See Coffey, New Grange, Dublin, I9I2). Now the surface of one such (on the right hand as you go in, at the narrowest part) has been made smooth by chiselling before the ornament was applied; and the marks of the instrument used can still be seen very plainly. It was a chisel with an edge very slightly serrated or chipped, doubtless by use. The upright stone is of a soapy texture. I do not think that anything but a metal chisel could have done this. It would be interesting to know whether, in the Dublin Museum, there are any bronze chisels whose working edge agrees in width with these marks; and if so to what period of the Bronze Age the type belongs. It is difficult also to see how the elaborate and sometimes deep incisions on the stones of New Grange and kindred Irish monuments can have been made except with metal tools. Some of this ornament can be proved to have been sculptured before the stones were placed in their present position.

About 640 yards to the south-east of New Grange is a large round barrow standing in the centre of a circular earthen rampart. The diameter of this circle is 154 yards. Comparisons are suggested with the disc-barrows of Southern England and with the Giant's Ring in Antrim. The present example differs, however, from disc-barrows both in the size of the central mound, and in the absence of any visible ditch associated with the bank. The Giant's Ring has a stone burialchamber at the centre. One of the four earthen rings near the Castle 